\title{
Food Waste in a School Nutrition Program After Implementation of New Lunch Program Guidelines
}

\begin{abstract}
Authors: Carmen Byker Shanks, Alisha R. Farris, Michael Marcenelle, George C. Davis, \& Elena L. Serrano
\end{abstract}

NOTICE: this is the author's version of a work that was accepted for publication in Journal of Nutrition Education and Behavior. Changes resulting from the publishing process, such as peer review, editing, corrections, structural formatting, and other quality control mechanisms may not be reflected in this document. Changes may have been made to this work since it was submitted for publication. A definitive version was subsequently published in Journal of Nutrition Education and Behavior [VOL\# 46, ISSUE\# 5, (September 2014)] DOI\# 10.1016/j.jneb.2014.03.009

Byker, Carmen J., Alisha R. Farris, Michael Marcenelle, George C. Davis, and Elena L. Serrano. "Food Waste in a School Nutrition Program After Implementation of New Lunch Program Guidelines." Journal of Nutrition Education and Behavior 46, no. 5 (September 2014): 406-411. doi: 10.1016/j.jneb.2014.03.009.

Made available through Montana State University's ScholarWorks scholarworks.montana.edu 
Title Page

Title Food Waste in a School Nutrition Program After Implementation of New NSLP Guidelines Section Research Article

Authors Carmen J Byker, PhD (corresponding author), Montana State University, Department of Health and Human Development, 222 Romney Gym, Bozeman, MT 59717, Tel (406) 9941952, Fax (406) 994-6314, carmen.byker@montana.edu Alisha R Farris, MS, RD, Virginia Tech, Department of Human Nutrition, Foods and Exercise, Wallace Annex, Blacksburg, VA, 24061; Tel (501) 358-9264, alisha@,vt.edu Michael Marcenelle, Montgomery County Public Schools, 750 Imperial Street SE, Christiansburg, VA 24073, Tel (540) 382-5100 ext1100, Fax (540) 394-4445, marcenel@,mcps.org George C Davis, PhD, Virginia Tech, Department of Agricultural and Applied Economics and Department of Human Nutrition, Foods and Exercise, 214 Hutcheson Hall, Blacksburg, VA 24061, Tel (540) 231-6783, Fax (540) 231-7417, georgedavis@vt.edu

Elena L Serrano, PhD, Virginia Tech, Department of Human Nutrition, Foods and Exercise, 201 Wallace Annex, Blacksburg, VA, 24061; Tel (54) 231-3464, serrano@,vt.edu AcknowledgementsThe authors would like to thank Melody Bowen, Linsey Kummer, ShaCoria Winston, Ramine Alexander, Felicia Reese, and Shaun Reib for their contributions to this research. 
TITLE Food Waste in a School Nutrition Program After Implementation of New NSLP Guidelines

\section{STRUCTURED ABSTRACT}

Objective The aim of this study was to assess the amount of food waste by meal components (main entrée (grain and meat), fruit, vegetable, milk) according to the new NSLP guidelines among early elementary students (pre-kindergarten and kindergarten).

Design For five consecutive school days, the research team collected school lunch trays and meal components were separated into bins relative to each food or beverage appearing on the school's daily menu.

Setting Food waste observations were made in one elementary school utilizing the NSLP guidelines.

Participants 304 meals from one pre-kindergarten class and five kindergarten classes. Variables Measured Food waste

Analysis Bins were weighed in grams and converted to ounces and cups at the end of each lunch period. Proportions of food wasted by amount of food served were calculated and reported as descriptive statistics.

Results Of 4,988 ounces of food and beverages served, 2,261 ounces (45.3\%) were wasted during one full school week, totaling 141 pounds. The greatest amount of food waste was generated from vegetables, main entrée, and milk, respectively.

Conclusions and Implications Strategies to reduce food waste in school lunch should be researched and implemented.

ABSTRACT WORD COUNT 189 words

KEYWORDS National School Lunch Program; food waste; plate waste; nutrition; children 


\section{INTRODUCTION}

The National School Lunch Program (NSLP) is one of the largest federal food assistance programs operating in the US. Established in 1946 and administered by the US Department of Agriculture, the NSLP serves more than 31 million students each day across 100,000 schools with $\$ 11.1$ billion to administer in FY $2011 .^{1}$ In 2010, the Healthy Hunger-Free Kids Act $^{2}$ updated the meal patterns and nutrition standards for the NSLP (and the School Breakfast Program) to align with the 2010 Dietary Guidelines for Americans and in response to the Institute of Medicine Report on Nutrition Standards for Schools. ${ }^{3}$ In order to "meet the nutrition needs of school children" and to "enhance the diet and health of school children, and help mitigate the childhood obesity trend," the NSLP began to implement significant changes during school year 2012-2013. ${ }^{4}$

The new standards aim at improving the nutritional quality of foods in schools, enhancing nutrition education materials for parents, and expanding eligibility for low-income children to enroll in school meals. ${ }^{5}$ The revised NSLP guidelines focus on providing five meal components, fruits, vegetables, whole grains, low-fat dairy, and protein, with serving sizes and calories now based upon age and grade-level. The new guidelines also require a daily serving of fruit, vegetables, plus a weekly requirement for dark green, red/orange, beans/peas, starchy, and other vegetables. Under Offer Versus Serve guidelines, which is mandatory for high schools and elective for elementary and middle schools, students must select at least $1 / 2$ cup of fruits and/or vegetables in order for schools to be in compliance and reimbursed. ${ }^{5}$ The Healthy Hunger-Free Kids Act requires an increased federal reimbursement rate for school lunches by 6 cents to help compliance with federal nutrition standards. ${ }^{6}$ 
While public health advocates have applauded the new NSLP standards, popular press implies that the new standards, in particular those related to fruits and vegetables, have led to increased levels of food waste. ${ }^{7,8}$ These claims are based on anecdotal evidence, however, and not scientifically gathered data. The aim of this study was to assess the amount of food waste by food and beverage category within the NSLP among early elementary students (pre-kindergarten and kindergarten) to serve as a baseline assessment for future studies and as a reference point. To date, no research has been published to assess food waste as part of the new standards. Existing studies on school food waste are based on previous standards and many focus on food waste of specific meal components (i.e. fruits and vegetables) rather than the entire meal. ${ }^{9-12}$ Further, the studies have focused on older elementary and middle school audiences. ${ }^{13,14}$ This age group represents a relatively "new" audience given their length of time and exposure to the NSLP. Therefore, strategies to improve consumption and waste within the NSLP may be more effective within this age group. This age is also considered a critical stage in fostering food preferences for lifetime health. ${ }^{15}$ The secondary aim was to identify food and/or beverage categories with the highest level of food waste. In this study, food waste is defined as the quantity of edible food and beverage served as part of the NSLP and not consumed.

\section{METHODS}

Participants and Setting. One pre-kindergarten and five kindergarten classes (referred to as study classrooms) from a single public elementary school were recruited to participate in the study. In

[the state where this study was conducted], pre-school and pre-kindergarten are integrated on-site with the K-5 public school system. Although the standards are not mandated for prekindergarten, the school adhered to the NSLP guidelines for this group. The eligibility for free and reduced price school lunch at the school is $48.93 \%$ for $2012-2013$ [blinded]. The school is 
located in a large town with a population of 21,030 and $89.5 \%$ white, $6.2 \%$ black, and $2.2 \%$ Hispanic/Latino individuals. It is located in a rural county in the southwest region of the US [blinded location]. ${ }^{16}$

Measures. Data collection occurred for one full week in March 2013 to capture potential changes by day of the week and by menu offerings. Each day, school nutrition staff standardized, preweighed, and served each food item on a school lunch tray. See Figure 1. Fruit and vegetable juices and milk were served in cartons. See Table 1. All menu items were then weighed and recorded each day by the research staff. An observation checklist was used to record which NSLP food and beverages were served to each student enrolled in the study classrooms and if the meals actually met the NSLP guidelines for each food component. The research team validated that all requirements were met for fruits, vegetables, grains, meat/meat alternate, and milk. The county's menus have been submitted to the Office of School Nutrition Programs, [state where this study was conducted], Department of Education, for Certification of Compliance with the New Meal Pattern and Nutrition Standards. Each observational checklist was tailored to reflect the meal components of the day's specific menu. Researchers photographed meals to capture food quality and presentation. Researchers also recorded class size and number of NSLP school lunches served by class.

Food Waste. To compute the amount of food waste, bins were prepared to collect food by each food and beverage appearing on the school's daily menu (i.e., each different main entrée, fruit, vegetable, and milk). See Table 1. Fruit juice was collected in a bin separate from milk and fruits and then calculated within the fruit component of the meal. Before beginning collection, all bins were measured for tare weight. This school division's menus consistently combined meat and grains within the main entrées. The elementary school utilized Offer Versus Serve guidelines for 
all study classrooms and in the entire lunchroom. ${ }^{5}$ When students completed their meal, the research team collected school lunch trays and separated foods and beverages into their respective bins. The research team computed the edible potion of apples and plums by weighing the cores separately, averaging, and subtracting from mean fruit weight. Beverages were poured out of the cartons into the bins. At the end of each lunch period for each class, bins were weighed in grams and recorded by two independent research staff.

Data Collection and Analysis. Based on school preferences, no personal information was collected from students. The [blinded] Institutional Review Board declared the study exempt, since no personal and/or identifying information was collected from participants, only meals and food waste. The school division, school nutrition director, and principal approved this study. All food and beverage weights were collected and recorded using ZIEIS ${ }^{\mathrm{TM}}$ digital scales, accurate to $5 \mathrm{~g}$, in grams, then converted to ounces and cups using Microsoft Excel 2010 (version 14.0). Proportions of food wasted by amount of food served were calculated and reported as descriptive statistics in order to account for differences in weight of each specific menu item.

\section{RESULTS}

Participants and Setting. In total, 304 school lunches were observed during the study period. Food waste from one pre-kindergarten with 73 students and five kindergarten classes with 231 students was observed at one elementary school.

Food Served and Wasted. Of 4,988 ounces of food and beverages served, 2,261.2 ounces (45.3\%) were wasted during one full school week, totaling 141.2 pounds. See Table 2. Per student, total of 16.4 ounces (1.03 pounds) of food and beverage were served: 9.0 ounces of food and 7.4 ounces of milk. By student, this averaged to 7.4 ounces ( 0.46 pounds) of food waste: 4.1 ounces for food and the remaining 3.4 ounces for milk. 
Food waste was highest on Monday (53.0\%) and lowest on Tuesday (35.5\%). Vegetables (51.4\%) were wasted in the greatest amount, followed by main entrée (51.0\%), and milk (45.5\%). Fruit had the lowest level of waste (33.0\%). When converted to cups, 38.2 cups of 130.5 cups fruit servings were wasted. For fruit, the proportion wasted by day ranged from $21.4 \%$ to $42.3 \%$. For vegetables, the daily range was between $26.1 \%$ and $80.1 \%$. Of 139.8 cups of vegetables served, 92.6 cups were wasted. Although data were not collected on children's perceptions of the meals (i.e. quality, taste, appearance), the research team noted high quality and appetizing meal items. See Figure 1.

\section{DISCUSSION}

In this study, food waste was surprisingly high with almost half of all food that was served actually thrown away (45.3\%). Although no other studies exist to compare with the new standards or with this specific age group, a limitation, in one study among a higher proportion of food insecure students, $99 \%$ eligible for free and reduced price NSLP, food waste was $37 \%,{ }^{13}$ substantially lower than in our study. Other studies have found food waste to be as low as $10 \% .{ }^{17}$ In a study conducted by Adams and colleagues (2005) with first through fifth graders in four California schools, food waste for fruits and vegetables ranged from $43 \%$ to $69 \%$, which corresponded to the middle range of our results. ${ }^{11}$ Another study provided a cost estimate of $\$ 432,349$ for food waste at lunch during one school year. ${ }^{14}$ Based on estimates of the most frequently charged price for elementary students costing $\$ 2.15,{ }^{18}$ our food waste results (45.3\%) cost $\$ 0.97$ per meal, or $\$ 286.08$ of food discarded from the 304 meals observed during the study period. Further research needs to be conducted in order to make better conclusions about food waste and the new NSLP guidelines. 
Clearly some level of food waste is expected at schools and across settings. To date, no standards or goals have been set across any setting (i.e. schools, institutions, home), which would be beneficial. ${ }^{19}$ Food waste is an increasingly important issue to address, given attention on accountability of governmental resources coupled with costs of implementing the NSLP. ${ }^{2}$ High levels of food waste threaten the dietary goals of the program and result in added costs to the NSLP, such as disposal costs, over-purchasing, and labor, not to mention several potential environmental concerns, such as inefficient resource utilization to grow and transport food (i.e. water, fertilizers, and energy), greenhouse gas emissions, and public health concerns, such as sanitation. $^{20}$

\section{The NSLP is designed to meet 1/3 of Recommended Daily Allowances RDAs for key} nutrients over the span of one week, ${ }^{21}$ if food is being wasted, then important dietary needs are not being met for NSLP participants. Our food waste results indicate that participants ate 54.7\% of their food and received roughly $1 / 5$ of their RDA. Compared to another study with middle school students in an urban area during 2007-2009, our results had lower proportions of fruit and vegetable waste and higher amounts of entrée and milk waste. ${ }^{14}$ The amount and types of food served may need to be reconsidered if the primary nutrition goal of NSLP is to be met.

In general, large-scale, community-wide strategies need to be considered to reduce food waste and improve dietary intake, while maximizing resources. Americans wasted 34 million tons of food in 2010 alone. ${ }^{20}$ Given the recently released Academy of Nutrition and Dietetics position statement supporting "that all people should have consistent access to an appropriately nutritious diet of food and water" and stating "870 million people have inadequate food energy intake" worldwide, food waste is one important component of addressing food insecurity and the notion of "waste not want not. ${ }^{22}$ To help accomplish this goal, it is important that we develop 
food systems that achieve nutrition security for all, starting by decreasing or diverting food waste, distributing in a more equitable manner, and creating a culture that more highly values food.

Perhaps high levels of food waste in this study and in the US can partially be attributed to changes in societal norms from pressuring children to "clean their plate" to promoting selfregulation and control. ${ }^{23,24}$ Perhaps a balance between understanding appetite, choosing the appropriate amount of foods for nourishment, and cleaning the plate to reduce food waste needs to be struck. Currently, NSLP participants choose one food or beverage from each meal component category and serving sizes are served according to the new NSLP guidelines. The NSLP participant then has the autonomy to consume or waste foods. Implementing simple strategies, aligned with the Smarter Lunchrooms initiatives, can "nudge" students into consuming healthy foods. ${ }^{25}$ These strategies focus on behavioral economics, which target increasing attractiveness, convenience, and normativeness of healthy foods in the cafeteria. ${ }^{26,27}$ For example, using food names to appeal to youth may impact choices in the lunch line and consumption at the table. ${ }^{28}$ Other strategies include taste testing, recess before lunch, noise control, and the timing of lunch. ${ }^{25}$

Limitations. The menu was specific to a school division/district, although in compliance with the NSLP guidelines, which should generally be consistent across school divisions in other locations. Estimated intake may not be generalizable due to cultural and social norms toward food choices and food waste. No data were collected on food exposure, home environment, and food preferences. Food waste may be attributed to the fact that the new guidelines were implemented just months before the study occurred and students may not be accustomed to "new" foods being served. Research also shows that younger students tend to waste more food, so this estimate may 
not be generalizable beyond the pre kindergarten and kindergarten age group. Still, it offers a baseline assessment of the acceptability of the NSLP guidelines among relatively 'new' audiences of the NSLP. Finally, no baseline data were available to compare to food waste rates prior to implementation of the new standards. Given the school's desire to protect the privacy of the children, data on food served and wasted on a child-level were not collected. As a result, only descriptive statistics could be reported and statistical tests could not be performed to detect differences by day, individual student, or menu. Still, substantial and consistent differences were noted throughout the week. For example, with the exception of the one day that mashed potatoes were offered, vegetables were the highest food waste category.

\section{IMPLICATIONS FOR RESEARCH AND PRACTICE}

This study represents the first school food waste study conducted since the implementation of the NSLP standards were put in place in fall 2012. This study can be used as a timestamp to compare food waste (and consumption) over time, given the new requirements. Further studies are warranted to track food waste by individual child, reasons for food waste (e.g., serving sizes, time given to consume food, noise levels in cafeteria), and across different schools representing more diverse audiences (socio-economic status, race, ethnicity), along with other socio-ecological influences. Strategies to reduce food waste should also be employed. 


\section{REFERENCES}

1. US Department of Agriculture, Food and Nutrition Service. National School Lunch Program Fact Sheet. http://www.fns.usda.gov/cnd/lunch/AboutLunch/NSLPFactSheet.pdf. Accessed October 10, 2012.

2. $111^{\text {th }}$ US Congress. Healthy Hunger-Free Kids Act 2010, Public Law 111-296. www.gpo.gov/fdsys/pkg/PLAW-111pub1296/pdf/PLAW-111publ296.pdf. Published December 13, 2010. 124 STAT. 3183. Accessed October 10, 2012.

3. Institute of Medicine. Nutrition Standards for Foods in Schools: Leading the Way toward Healthier Youth. http://www.iom.edu/Reports/2007/Nutrition-Standards-for-Foods-inSchools-Leading-the-Way-toward-Healthier-Youth.aspx. Accessed April 3, 2013.

4. US Department of Agriculture. Nutrition Standards in the National School Lunch and School Breakfast Programs; Final Rule. http://www.gpo.gov/fdsys/pkg/FR-2012-01-26/html/20121010.htm. Published January 26, 2012. 77 Federal Registrar 17. Accessed October 10, 2012.

5. US Department of Agriculture. Nutrition Standards in the National School Lunch and School Breakfast Programs; Final Rule. http://www.gpo.gov/fdsys/pkg/FR-2012-01-26/html/20121010.htm. Published January 26, 2012. 77 Federal Registrar 17. Accessed October 10, 2012. $111^{\text {th }}$ US Congress. Healthy Hunger-Free Kids Act 2010, Public Law 111-296.

6. US Department of Agriculture, Food and Nutrition Service. Summary of The Healthy, Hunger-Free Kids Act of 2010 (By Program). http://www.fns.usda.gov/cnd/Governance/Legislation/PL111-296_Summary.pdf. Accessed April 3, 2013. 
7. Plumlee R. The Wichita Eagle. Wasted food a worry for schools. http://www.kansas.com/2012/12/01/2587528/wasted-food-a-worry-for-schools.html. Accessed April 3, 2013.

8. Moser D. More food goes to waste under new guidelines. http://www.eagletribune.com/local/x1533630100/More-food-goes-to-waste-under-newguidelines. Accessed April 2, 2013.

9. Buzby J, Guthrie J. Plate Waste in School Nutrition Programs. 2002. US Department of Agriculture, Economic Research Service. http://naldc.nal.usda.gov/download/48204/PDF. Accessed April 3, 2013.

10. Guthrie J, Buzby J. Several strategies may lower plate waste in school feeding programs. Food Review. 2002;25(2):36-42.

11. Adams M, Pelletier R, Zive M, Sallis J. Salad bars and fruit and vegetable consumption in elementary schools: a plate waste study. J Am Diet Assoc. 2005;105(11):1789-1792.

12. Marlette M, Templeton S, Panemangalore M. Food type, food preparation, and competitive food purchases impact school lunch plate waste by sixth-grade students. J Am Diet Assoc. 2005;105(11)1779-1782.

13. Reger C, O’Neil C, Nicklas T, Myers L, Berenson GS. Food waste of school lunches served to children in a low-socioeconomic elementary school in south Louisiana. School Food Service Research Review. 1996;20:13-19.

14. Cohen J, Richardson S, Austin S, Bryn Austin, S, Economos C, Rimm E. School lunch waste among middle school students: nutrients consumed and costs. Am J Prev Med. 2013;44(2):114-121. 
15. Birch L, Savage JS, Ventura A. Influences on the development of children's eating behaviours. From infancy to adolescence. Can J Dietetic Pract Res. 2007;68(1):S1-S4, S6.

16. US Census Bureau. http://www.census.gov/\#. Accessed April 3, 2013.

17. St. Pierre R, Fox M, Puma M, Glantz F, Moss M, Endahl J. 1992. Child Nutrition Program Operations Study, Second Year Report: Executive Summary. US Department of Agriculture, Food and Nutrition Service, Office of Analysis, Nutrition, and Evaluation (USDA/FNS).

18. US Department of Agriculture, Food and Nutrition Service. School Food Authority Paid Lunch Price Report. http://www.doe.virginia.gov/support/nutrition/statistics/meal_prices/2012-2013.pdf. Accessed April 10, 2013.

19. US General Accounting Office (USGAO). Waste from School Lunches. GAO/RCED-96128R. Washington DC, May 8, 1996.

20. US Environmental Protection Agency. Reducing Food Waste for Business. http://www.epa.gov/waste/conserve/foodwaste/. Accessed April 10, 2013.

21. US Department of Agriculture, Food and Nutrition Service. USDA School Meals: Healthy Meals, Healthy Schools, Healthy Kids. http://www.fns.usda.gov/cga/factsheets/school_meals.htm. Accessed April 3, 2013.

22. Nordin S, Boyle M, Kemmer T. Position of the academy of nutrition and dietetics: nutrition security in developing nations: sustainable food, water, and health. $J$ Acad Nutr Diet. 2013;113(4):581-595.

23. Birch L, McPhee L, Shoba B, Steinberg L, Krehbiel R. "Clean up your plate": effects of child feeding practices on the conditioning of meal size. Learning and Motivation. 1987;18(2):301-317. 
24. Costanzo P, Woody E. Domain-specific parenting styles and their impact on the child's development of particular deviance: the example of obesity proneness. Journal of Social and Clinical Psychology. 1985;3(4):425-445.

25. US Department of Agriculture, Food and Nutrition Service. Smarter Lunchrooms. http://healthymeals.nal.usda.gov/healthierus-school-challenge-resources/smarter-lunchrooms. Accessed January 20, 2013.

26. Just DR, Wansink B. Smarter lunchrooms: using behavioral economics to improve meal selection. Choices. 2009;24(3):19.

27. Hanks A, Just D, Wansink B. Smarter lunchrooms: libertarian paternalism can address new school lunchroom guidelines and childhood obesity. smarterlunchrooms.org/sites/default/files/slm-jped-with-tables_12-20-12.pdf. Accessed January 20, 2013.

28. Wansink B, Just DR, Payne CR, MZ Klinger. Attractive names sustain increased vegetable intake in schools. Prev Med. 2012;55(4):330-2. 
Table 1. Menu Items by Day of the Week in a School Nutrition Program After Implementation of New NSLP Guidelines

\begin{tabular}{|c|c|c|c|c|}
\hline Category + & Monday & Tuesday & Wednesday & Thursday \\
\hline $\begin{array}{l}\text { Main } \\
\text { Entrée }\end{array}$ & $\begin{array}{l}\text { Taco; Veggie wrap; } \\
\text { Chef salad; PBJ* } \\
\text { sandwich }\end{array}$ & $\begin{array}{l}\text { Hot dog; Grilled cheese } \\
\text { sandwich; Taco salad; } \\
\text { PBJ sandwich }\end{array}$ & $\begin{array}{l}\text { Cheese quesadilla; } \\
\text { Chicken filet sandwich; } \\
\text { Chef salad; PBJ } \\
\text { sandwich }\end{array}$ & $\begin{array}{l}\text { Asian chicken salad; } \\
\text { Quiche; Chicken fajit; } \\
\text { salad; PBJ sandwich }\end{array}$ \\
\hline Fruit & $\begin{array}{l}\text { Applesauce; Plums; } \\
\text { Oranges; Apple; Apple } \\
\text { juice; Orange juice }\end{array}$ & $\begin{array}{l}\text { Strawberries; Pears; } \\
\text { Applesauce; Apple } \\
\text { juice; Orange juice }\end{array}$ & $\begin{array}{l}\text { Peaches; Plums; Pears; } \\
\text { Apple juice; Orange } \\
\text { juice }\end{array}$ & $\begin{array}{l}\text { Mixed fruit; Apples; } \\
\text { Plums; Apple juice; } \\
\text { Orange juice }\end{array}$ \\
\hline Vegetable & $\begin{array}{l}\text { Refried beans; } \\
\text { Broccoli; Corn; Side } \\
\text { salad }\end{array}$ & $\begin{array}{l}\text { Vegetable beef broth; } \\
\text { Green peas; Coleslaw; } \\
\text { Tomato juice; Side } \\
\text { salad }\end{array}$ & $\begin{array}{l}\text { Sweet potatoes; Green } \\
\text { beans; Sandwich } \\
\text { condiments: lettuce, } \\
\text { tomato, pickles; } \\
\text { Spinach; Side salad }\end{array}$ & $\begin{array}{l}\text { Chinese veggies; } \\
\text { Mashed potatoes; } \\
\text { Garlic broccoli; Side } \\
\text { salad }\end{array}$ \\
\hline Milk & $\begin{array}{l}\text { Low-fat unflavored } \\
\text { milk; Strawberry non- } \\
\text { fat milk; Chocolate } \\
\text { non-fat milk }\end{array}$ & $\begin{array}{l}\text { Low-fat unflavored milk; } \\
\text { Strawberry non-fat milk; } \\
\text { Chocolate non-fat milk }\end{array}$ & $\begin{array}{l}\text { Low-fat unflavored milk; } \\
\text { Strawberry non-fat milk; } \\
\text { Chocolate non-fat milk }\end{array}$ & $\begin{array}{l}\text { Low-fat unflavored } \mathrm{m} \\
\text { Strawberry non-fat } \mathrm{m} \\
\text { Chocolate non-fat } \mathrm{mi}\end{array}$ \\
\hline
\end{tabular}

${ }^{*}$ PBJ sandwich denotes peanut butter and jelly sandwich

†School lunch participants choose one main entrée, at least $1 / 2$ cup of fruits and/or vegetables, and milk

Table 2. Food Waste among Pre-Kindergarten and Kindergarten Students Participating in the National School Lunch Program by 


\begin{tabular}{|c|c|c|c|c|c|c|c|c|c|c|}
\hline Day/Food & \multicolumn{2}{|c|}{$\begin{array}{l}\text { Monday } \\
(n=59)\end{array}$} & \multicolumn{2}{|c|}{$\begin{array}{l}\text { Tuesday } \\
(n=56)\end{array}$} & \multicolumn{2}{|c|}{$\begin{array}{l}\text { Wednesday } \\
\qquad(n=60)\end{array}$} & \multicolumn{2}{|c|}{$\begin{array}{c}\text { Thursday } \\
(n=60)\end{array}$} & \multicolumn{2}{|c|}{$\begin{array}{l}\text { Friday } \\
(n=69)\end{array}$} \\
\hline Category & $\begin{array}{c}\text { Food Served } \\
(\mathrm{oz})\end{array}$ & $\begin{array}{c}\text { Food Wasted } \\
\text { (oz) }\end{array}$ & $\begin{array}{c}\text { Food Served } \\
\text { (oz) }\end{array}$ & $\begin{array}{c}\text { Food Wasted } \\
\text { (oz) }\end{array}$ & $\begin{array}{c}\text { Food Served } \\
(\mathrm{oz})\end{array}$ & $\begin{array}{c}\text { Food Wasted } \\
\text { (oz) }\end{array}$ & $\begin{array}{c}\text { Food Served } \\
(\mathrm{oz})\end{array}$ & $\begin{array}{c}\text { Food Wasted } \\
\text { (oz) }\end{array}$ & $\begin{array}{c}\text { Food Served } \\
(\mathrm{oz})\end{array}$ & $\mathrm{Fo}$ \\
\hline Main Entrée & 346.5 & 218.5 & 239.6 & 92.5 & 327.1 & 178.5 & 305.7 & 160.6 & 302.9 & 125 \\
\hline Vegetable & 69.6 & 55.7 & 61.2 & 39.6 & 102.4 & 56.6 & 169.9 & 44.3 & 80.3 & 52.2 \\
\hline Milk & 503.6 & 247.1 & 461.0 & 163.1 & 486.6 & 247.2 & 503.6 & 214.3 & 563.4 & 232 \\
\hline TOTAL & 1120.3 & 597.8 & 941.2 & 335.8 & 1128.1 & 564.7 & 1169.0 & 508.3 & 1214.8 & 50 \\
\hline
\end{tabular}

$\mathrm{n}$ refers to the number of NSLP meals observed across pre-kindergarten and kindergarten classes by day

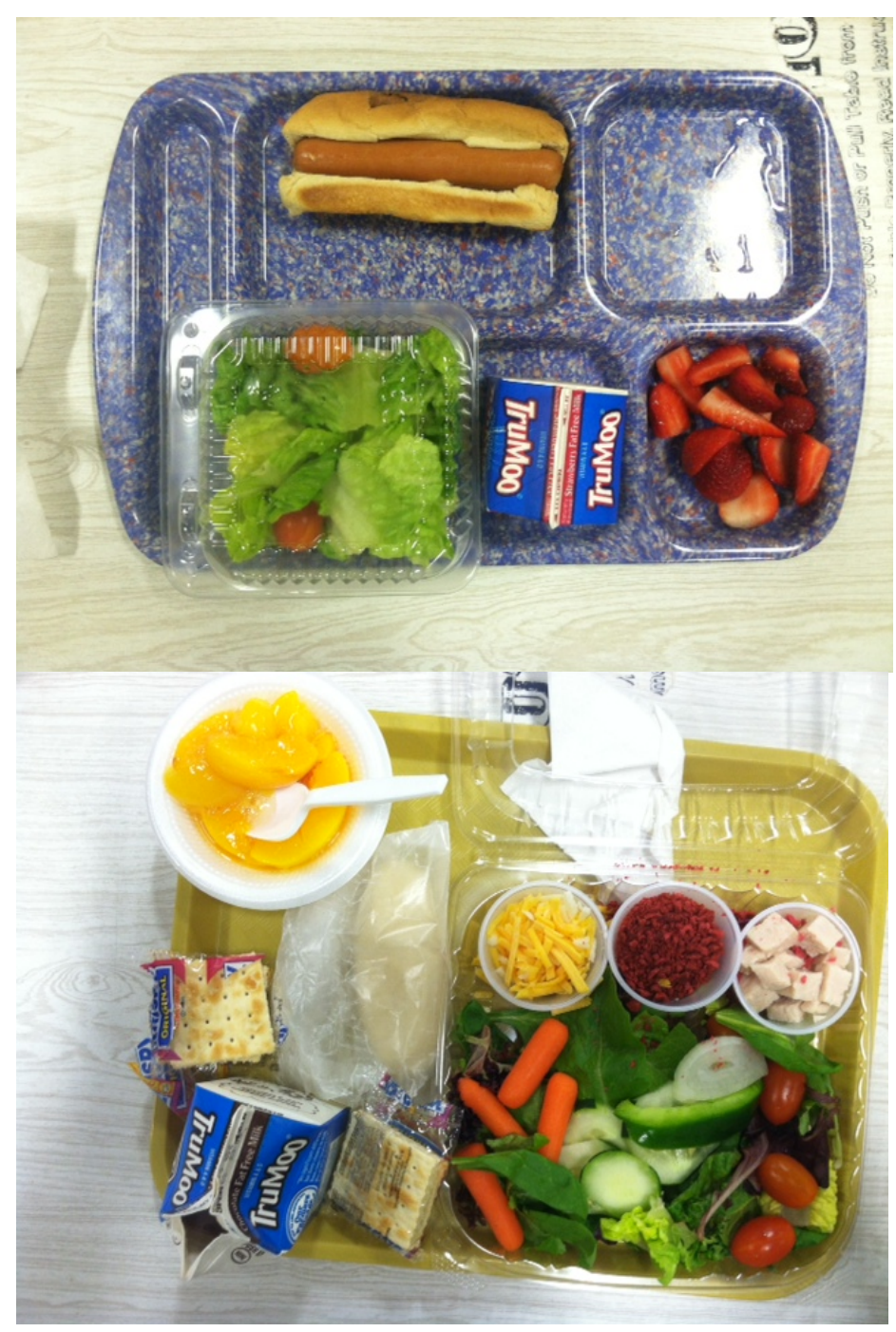

Figure 1. Sample of National School Lunch Program Meal on Tuesday (left) and Wednesday ( 